\title{
Ethnic conflict and gender inequality in education: the case of Turkey
}

\author{
Ramazan Kılınç ${ }^{\mathrm{a}}$, Jody Neathery-Castro ${ }^{\mathrm{a}}$ and Selin Akyüz \\ aDepartment of Political Science, University of Nebraska-Omaha, Omaha, NE, USA; \\ binternational Advanced Studies Centre, Bilkent University, Ankara, Turkey
}

\begin{abstract}
Although conflict remains a major obstacle to development in many areas of the world, its impact on education has been rarely studied. This article investigates the relationship between conflict and gender equality, focusing on the schooling of the girls in the conflict-ridden regions of Turkey. Patriarchy is the most important determinant of low educational levels among girls in Southeastern Turkey. However, ethnic conflict exacerbates male-dominant traditions and blocks economic development, reinforcing patriarchal norms and limiting girls' school attendance. Yet, by provoking political mobilization around a Kurdish identity, ethnic conflict may undermine patriarchy and unintentionally promote girls' education.
\end{abstract}

ARTICLE HISTORY Received 22 March 2017; Accepted 29 September 2017

KEYWORDS Gender inequality; ethnic conflict; education; Kurdish conflict; Turkey

Despite Turkey's economic growth in recent years, disparities still exist with respect to closing the gender gap in educational achievement. The most disadvantaged groups in education are young girls in southeastern regions who do not have Turkish as their mother tongue. ${ }^{1}$ According to a 2010 UNESCO report on educational opportunities, 43\% of Kurdishspeaking girls have less than two years of education, while this number is only $6 \%$ for girls among other populations of Turkey. Those who speak Kurdish at home in Turkey have a 30\% risk of earning less than four years of schooling compared with a comparable risk of less than 5\% for Turkish speakers. ${ }^{2}$ Those figures are even more striking when one compares Turkey with other educationally underperforming countries. Turkey is economically the most developed state among those states that have similar records of gender inequality in education. These facts and figures,

CONTACT Ramazan Kılınç rkilinc@unomaha.edu Department of Political Science, University of Nebraska at Omaha, 6001 Dodge St., ASH 275, Omaha, NE 68182, USA

This article was originally published with errors. This version has been corrected. Please see erratum (http://dx.doi.org/10.1080/14683849.2018.1467825).

(c) 2017 Informa UK Limited, trading as Taylor \& Francis Group 
particularly the gap between Kurdish girls and other groups in terms of educational attainment, point to a possible relationship between Turkey's Kurdish conflict and girls' education. It is this relationship that we examine in this study.

A number of scholars point to socio-economic marginalization as the explanation for the low level of schooling for girls. ${ }^{3}$ Many have argued that language and ethnicity differences for minority groups is a significant source of marginalization in education. ${ }^{4}$ Others suggest looking at cultural patterns and argue that patriarchal social structure is the key to understanding the low level of girls' education. ${ }^{5}$ In this study, we contribute to this literature by investigating how the conflict between the Turkish state and the Kurds in Southeastern Turkey influences gender equality in education. Kurds and Arabs are the minority groups included in the study, as they make up the minority population in the cities we sampled. As minority groups, they can be expected to share certain experiences, such as some degree of marginalization from the state. However, we anticipate the long-running conflict disproportionately influenced the Kurds. The state allowed the expression of the Kurdish ethnic identity only in the early 2000s, phasing out discriminatory policies without fully solving the decades-old problems. ${ }^{6}$ In 2015, the issue resurfaced and a military clash between the state and Kurdish separatists reignited.

We argue that ethnic conflict exacerbates gender inequality in education in three possible ways. First, violence reinforces traditional societal patriarchal structures. Second, ethnic conflict inhibits the diffusion of national economic development that could ameliorate patriarchy's effects in the conflict-ridden regions of Turkey. Third, the fear of cultural assimilation might lead parents not to send their children to school. However, we find that the political mobilization of Kurdish identity undermined traditional patriarchal relations and promoted a national identity, unintentionally contributing to more schooling of girls.

The rest of the article is organized as follows. First, we review the existing literature on gender inequality in education. Second, we offer our own argument that links ethnic conflict and gender inequality in education. Third, we describe our methodology, particularly our case selection and fieldwork research design. Finally, we present our findings on the causes of gender inequality in education with special attention to the role of political conflict.

\section{Competing explanations: socio-economic structure, language, and patriarchy}

From the insertion of the Women and Armed Conflict plank in the Beijing Platform for Action to the July 2010 creation of the UN Women by the United Nations, the international community has increasingly acknowledged the impact of conflict on women. However, the studies that focus on the 
impact of conflict on gender inequality in education have been limited. In explaining gender disparities in education, scholars have focused on socioeconomic structures, ${ }^{7}$ identity markers such as language and ethnicity, ${ }^{8}$ and the culture of patriarchy. ${ }^{9}$ Although these explanations developed our understanding of gender inequalities, they provide little knowledge on the causal impact of conflict on gender inequality.

One group of scholars argues that schooling of girls depends on the socioeconomic status of the parents. As socio-economic status increases, the schooling of girls also increases. ${ }^{10}$ This perspective partially explains the lower level of schooling of girls in Eastern provinces of Turkey. The socioeconomic conditions in Eastern provinces are worse than in the Western provinces, despite the state's ambitious, four decade-long government program of regional development designed to promote the southeast and stem westward migration - the South-Eastern Anatolia Project (GAP). ${ }^{11}$ But one comprehensive study that examined ethnic disparities in school enrollment in the 1990s found lower rates of school attendance for girls (particularly Kurdish and Arab girls), even after controlling for both region and a variety of family socio-economic characteristics. ${ }^{12}$ The same study had similar findings for drop-out rates, noting that just $1.4 \%$ of ethnic Turkish girls did not complete the first grade, while up to $25 \%$ of ethnic Kurdish girls did not complete the first grade. ${ }^{13}$ These findings suggest that variables associated with ethnicity continued to produce disparities beyond the economic conditions of the families.

Scholars have examined the educational barriers created by not speaking the dominant language. Fluency in the dominant language in a society is a basic element of social integration and social mobility. Social exclusion has been a common condition among minority residents in Turkish city slum areas, which has affected their ability to access education. ${ }^{14}$ We examine the relative importance of this element and the role it plays in education for ethnic and linguistic minority groups, with a focus on the Kurdish minority that has been engaged in an ethnic conflict with the Turkish state. ${ }^{15}$ Stephen May argues that 'ethnic and national conflicts are most often precipitated when nation-states ignore demands for greater cultural and linguistic democracy. ${ }^{16}$ But research suggests that Kurdish girls in Eastern Turkey have more Turkish networks than boys and may be adopting the more dominant language (Turkish) in order to attain more economic and social freedom than boys. ${ }^{17}$

Some scholars argue that the patriarchal practices inherent in Turkish society inhibit schooling among girls. ${ }^{18}$ Patriarchy, which we can simply define as a system in which men largely hold power, is a dominant cultural characteristic of Turkish society not only in Southeastern Turkey but nationally. The early Turkish modernization in the 1920s, which is characterized by Westernization and secularization, co-opted women's concerns. ${ }^{19}$ The official 
narrative from this period suggests that women achieved emancipation, albeit through a form of 'state feminism' ${ }^{20}$ which entailed a repressive attitude toward any possibility of feminist organizations outside of the state. ${ }^{21}$ Women had to 'bargain with patriarchy' in the republican era through loyalty to republican morals, which first and foremost perceived them as (potential) wives and/or mothers. ${ }^{22}$ In this respect, modernizing reforms have also reproduced traditional social roles. ${ }^{23}$ However, 'the women question' in Turkey gained new voices throughout the years. The 1990s saw a rise of identity politics alongside new facets of feminisms in Turkey. Islamist politics and Kurdish movement challenged state-led interpretation of women's rights. ${ }^{24}$ Patriarchy gained a new conservative form under the rule of Justice and Development Party (Adalet ve Kalkınma Partisi, AKP), marked by policies exemplifying the intertwining of neoliberal, nationalist, and religious politics. ${ }^{25}$ Scholars who focus on intersectional analysis examine how patriarchy influences women in interaction with other forms of discrimination, such as ethnic identity, in different areas of life including civil society activism ${ }^{26}$ and citizenship relations. ${ }^{27}$ Patriarchy, in interaction with ethnic identity and religious convictions, influences girls' education in southeastern Turkey.

Ayşe Gündüz-Hoşgör and Jeroen Smits find that some clerics and tribal leaders block access to academic opportunities for girls in the name of tradition. ${ }^{28}$ Some scholars discover as people distance themselves from the tribal patriarchal structures, they become more comfortable about sending girls to school. ${ }^{29}$ Girls' chances of post-primary schooling are greater if they live in metropolitan areas and in less patriarchal families. ${ }^{30}$ However, research also argues that men continue to preserve their control over women even after the migration from rural to metropolitan areas. ${ }^{31}$ The institutional and cultural environment of patriarchy also exists in urban areas and reproduces traditional patriarchy in the cities. ${ }^{32}$

Early marriage remains one of the widespread patriarchal practices in eastern Turkey. ${ }^{33}$ As a recent study on girls' education with a feminist lens argues child marriage is a prevalent cultural practice in eastern Turkey. ${ }^{34} \mathrm{~A}$ study based on a survey with 966 women and focus group interviews with 90 women in southeastern Turkey finds girls are considered marriageable once they reach puberty with considerations regarding the protection of family honor, with most pressures coming from their parents. ${ }^{35}$ The same study also demonstrates that early marriage constitutes a barrier for continued education as well as has adverse consequences for physical, mental, and emotional well-being of the girls. ${ }^{36}$

Our fieldwork gives support to the patriarchy argument; however, to account for the strength of patriarchy in southeastern Turkey, one also needs to consider the decades-old conflict between the state and the Kurds and how the conflict sustained patriarchal relations for decades. Most scholars 
of sociology and political science who have investigated the situation of women in conflict focus their attention on physical, sexual, and economic effects. Only a few scholars have produced scholarly work on the impact of ethnic conflict on education of girls, and most of these studies have not identified clear causal mechanisms between conflict and education. Utilizing a feminist perspective, Lynn Davies explores how conflict influences schooling particularly in the reproduction of the gender roles of femininity and masculinity but she does not provide a causal explanation for the gender inequalities in education that stem from conflict-related political developments. ${ }^{37}$ A group of scholars have demonstrated how ethnic differences create variation in educational attainment outcomes but they are blind to gender differences in these inequalities. ${ }^{38}$ Along the same lines, others have demonstrated racial differences in educational achievement and attainment but they have left out both violent conflict and gender stratification in their analysis. ${ }^{39}$

A number of scholars have discussed the role of state in the sustenance of gender inequalities in education, some bringing up the issue of ethnic conflict. Nelly P. Stromquist, for example, examined the gender inequality in education in the context of the state's role in regulating and promoting educational processes. ${ }^{40}$ Although she does not directly discuss ethnic violence, this study provides insight to understand state intervention in educational regulation, a factor in most of the cases of ethnic violence. Another study that analyzed the connection between ethnic conflict and children's education focused on providing peacebuilding curriculum to children who are exposed to ethnic conflict, but it did not develop explanations for educational disparities among genders in conflict-ridden contexts. ${ }^{41}$ Political scientists such as Mary Caprioli have examined the relationship between state aggression and gender inequality but they have not specifically looked at gender inequality in education. Caprioli demonstrated that states with lower levels of gender equality exhibit higher levels of violence during international disputes; but does not address how ethnic conflict in a certain locality influences gender inequalities in education. ${ }^{42}$

What is missing in the literature is explicit casual mechanisms between ethnic conflict and gender inequality in education. In the next section, we attempt to develop an explanation in the Turkish context to fill this gap. In doing so, we first give a brief overview of the Kurdish conflict in Turkey, then we identify mechanisms through which ethnic conflict influences gender inequality in education.

\section{The Kurdish conflict and gender inequality in education}

The discriminatory policies toward the Kurdish minority that started in early 1920s translated into a violent conflict between the Turkish state and the Kurdish separatist terrorist group, the PKK (Kurdistan Workers Party), 
from the mid-1980s forward. This violent conflict has resulted in tens of thousands of deaths. Our research examines to what extent this decades-old conflict influenced lower levels of schooling among girls in Southeastern Turkey.

There are about 15-20 million Kurds living in Turkey, which constitute about $20 \%$ of the population. ${ }^{43}$ With the Turkish Republic built on the idea of a homogenous nation, the Kurdish identity was denied throughout the Republican period. The discriminatory policies included a ban on the Kurdish language, a replacement of Kurdish town names with Turkish ones, the rejection of Kurdishness as an identity, and exclusion from some public jobs. ${ }^{44}$

Implementing repressive state policies, the Turkish state could sustain the policy of denial without serious challenge from the Kurdish population until the late 1970s when the Kurdish political activism gained momentum with the formation of the PKK. In 1984, the PKK initiated armed conflict against the Turkish state. The state's response was harsh: the deployment of military troops to fight the PKK, the forced displacement of people, long terms of detention, and numerous human rights violations of Kurdish citizens. ${ }^{45}$

As Turkey advanced to European Union candidacy, the Turkish government began implementing reforms to ameliorate discrimination of the Kurds. In the first decade of the 2000s, the government started officially recognizing the Kurdish identity, allowing the teaching of the Kurdish language at schools, and improving human rights conditions. ${ }^{46}$ Although the government had an agenda of reaching a political solution to the Kurdish conflict between 2012 and 2015, ${ }^{47}$ it returned to the military tactics of the previous eras especially after June 2015 elections. The conflict that caused tens of thousands of deaths in the last three decades had an enduring influence across social and economic policies in Turkey. The disparity in the schooling of girls is not an exception.

Ethnic conflict contributes to low levels of schooling among girls in three possible ways. First, conflict reinforces patriarchal social relations. Patriarchy grows easier in conflict-ridden regions since militarization becomes part of everyday life. Because of the armed conflict in the southeastern Turkey, the masculinist structure of the society gained strength and the number and quality of educational institutions declined, reducing women's educational opportunities. ${ }^{48}$ Although there have been efforts to incorporate women into social and economic realm through projects such as Multi-Purpose Community Centers, ${ }^{49}$ with the excuse of safety and security, most projects for development left out women. ${ }^{50}$

Second, the prevalence of conflict, by creating obstacles for business investment, prevents both economic development and the transition of poor people into the middle class. Although the government promoted development projects such as the Southeastern Anatolian Project, these projects did not create enough opportunities to expand across all segments of society. Ongoing 
political instability in the region diminished their ability to decrease poverty and unemployment. ${ }^{51}$ Economic underdevelopment reinforces patriarchal social relations. Research suggests that rising economic opportunity, if broad enough, often correlates with a weakening of patriarchy. ${ }^{52}$

Third, the existence of ethnic conflict might deter Kurdish families from sending their children to school with the concern that their children may lose their cultural identity. Anna Grabolle Celiker notes that because of Kurds' migration to urban areas, 'more and more young women are going to school for longer, which leads to an accelerated Turkification of Kurds. ${ }^{53}$ However, our research suggests that the political mobilization of Kurds as a reaction to their discrimination actually created a more cosmopolitan identity, undermined patriarchal social relations, and contributed to the schooling of the girls.

\section{Data and methods}

To test our argument, we interviewed three types of samples in the cities of Şanlıurfa and Gaziantep. We chose two neighboring cities in southeastern Turkey, one is home to a significant ethnic minority, the other not. Both cities were chosen from the same region to provide some control on geographic area. Both cities are about the same size. According to the 2013 census, they both have a population of 1.8 million. In each city, we interviewed parents that vary in ethnicity and language. In Şanlıurfa, we interviewed 13 parents of Kurdish descent, and 14 parents of Arab descent in the urban poor Karşıyaka neighborhood. In Gaziantep, we interviewed nine Turkish parents from the urban poor Düztepe and Karşıyaka neighborhoods. We conducted all the interviews in Summer 2013.

The parents that we interviewed had all urban poor backgrounds. Most of the mothers did not go to school at all while many fathers did not have an elementary school degree. None of the 36 parents that we interviewed had college students or graduates in their families. The families all moved to the cities within the past two decades. The largest family had 12 while the smallest had five children among Kurdish and Arab families. Among ethnic Turkish families, the number of children in each family ranged from 3 to 10 .

Interviews with Kurdish and Arab parents in Şanlıurfa, controlled for the 'conflict' variable. The political conflict in Turkey was between the state and the Kurds; the state did not have a violent conflict with the Arab minority. By interviewing Turkish parents in Gaziantep, we hoped to control for both the 'conflict' and 'language and ethnicity' variables. Gaziantep is a neighbor city to Şanlıurfa and has a similar cultural environment. On the other hand, both in demographics and the history of politicization of ethnicity, Gaziantep is different from Şanlıurfa. Ethnicity is a significant political cleavage in Şanliurfa, which is home to a significant Kurdish population; in contrast, 
ethnic difference is not a significant issue of cleavage in Gaziantep. ${ }^{54}$ For this reason, interviewing Turkish parents in Gaziantep gives us a good opportunity to measure the influence of conflict and ethnic and linguistic identities on gender inequality in education, serving as an effective control group in the study.

Through case studies that focus on the mechanism between a purported cause and its effect, we identify the causes of effects. ${ }^{55}$ In addition to our examined variable, 'conflict,' we explore several other variables such as socio-economic structure, language and ethnicity, and culture through case studies. During our field research, we conducted semi-structured interviews in each sample. In both Şanlıurfa and Gaziantep, we reached parents by snowball sampling, identifying an initial group with relevant characteristics, those whose daughters did not get schooling. Then these initial subjects were asked to refer additional parents, and so on, to extend the sample size. Although snowball sampling seems to skew representation, teachers' involvement in the process decreased the impact of snowballing. As opposed to parents who would direct us to those participants with similar characteristics to them, the teachers channeled us toward parents with different backgrounds. The interviews included questions structured to match the variables that we aim to test: socio-economic structure, ethnicity, patriarchy, and conflict. ${ }^{56}$

\section{Analysis and findings}

In our interviews, patriarchal norms stand out as the single most important factor preventing parents from sending their daughters to school. Socio-economic factors also influence the schooling of girls but these factors show their impact through changing patriarchal relations. However, ethnic conflict plays a significant role in gender inequality in education by reinforcing both patriarchy and low socio-economic conditions. Surprisingly, politicization of Kurdish identity as an outcome of ethnic conflict plays an unexpected role in weakening patriarchal impacts that stem from social-tribal contexts, and contributing to girls' education.

\section{Ethnic conflict, security, and gender inequality in education}

The prevalence of conflict in southeastern Turkey contributes to the consolidation of patriarchal social relations. Militarism and violent struggle reinforce the dominance of males, especially in already patriarchal societies. ${ }^{57}$ Families in the region feel that women are in a relatively more vulnerable position, which leads parents to become more unwilling to send their daughters to school. As Ahmetbeyzade writes, Kurdish women face threefold oppression: from the Turkish state, the feudal/tribal system, and patriarchal familial authority. ${ }^{58}$ On the one hand, the relationship with the state within the context of 
ethnic conflict seems to reinforce patriarchy through creating a relatively more militant environment. On the other hand, that the conflict forced several Kurdish families to move to the cities seems to have contributed to the weakening of patriarchal relations and unintentionally increased schooling of the girls. Many of our interviewees indicated that their migration from rural to urban areas helped them defy patriarchy and send girls to schools.

Turkish, Kurdish, and Arabic cultures have been fed by somewhat similar cultural backgrounds with their histories intertwined in Middle Eastern geography. ${ }^{59}$ Patriarchy in the form of 'protecting girls' from threats is a widespread control mechanism for all of these groups in both cities. Chastity of women has been historically constructed as 'the marker of cultural authenticity. ${ }^{60}$ As a representation of varying customary and religious practices, this control intersects with conflict in the region and legitimizes itself with insecurity in tune with masculine norms. However, our field work shows differences in how our respondents perceived the safety of their daughters. While our Arab and Turkish respondents solely focused on moral safety in explaining why there were limitations to send girls to schools, our Kurdish respondents raised the concern of physical safety of their children.

Most of the Arab and some Turkish families had a motivation to limit their daughters' engagement with the larger society by not sending girls to school especially after they completed elementary education. A male Arab Şanlıurfa respondent in his late thirties who did not send his daughter to school after the sixth grade, for example, mentioned that some girls intermingled with boys in the parks and cafes instead of going to school. While some fathers showed distrust in their daughters, many others blamed the broader social setting for drawing their daughters' attention. They said they did not send the girls to school to protect their kids from external dangers that await the girls outside.

Turkish parents in Gaziantep raised similar concerns about the girls' chastity. A father in Gaziantep noted, 'My girl became very attractive. Her height, her body was very attractive. So, we got afraid of gossip and I decided to not let her go to the school. But she was also very unwilling to go.' Although fathers generally highlighted these concerns, mothers frequently legitimated their husbands and argued 'the outside world is not safe for a girl who cannot protect herself.' Not just men reinforce patriarchy, women also reproduce traditional hierarchical gender relations by naturalizing those relations. Tradition works explicitly or implicitly as a regulator of gendered hierarchy, with patriarchy found in between, above or behind structures, networks and discourses.

Although we heard similar concerns of chastity from Kurdish parents, physical safety was the main theme about security of the girls in the Kurdish interviews. One older woman in her sixties related her concerns 
about the safety of her grandchildren who lived with her along with the mother of the children. She mentioned that her son was lost about 20 years earlier and she had to take care of her grandchildren. She raised concerns about her granddaughters and grandsons when they were not at home. A father in his early fifties also mentioned the security of the environment and said that he decided not to send his two daughters to school when they came to the middle-school age. Those who have concerns about the safety of the neighborhood prefer that their daughters use the school bus. A father in his forties mentioned, 'My daughter used the school bus. It is very expensive. My son walked to school.' While both of this family's children went to the same school, their daughter was not allowed to walk to school. Their mother added, 'Girls are much more exposed to threats in the streets.'

Ethnic conflict, through increased militarization, appears to reinforce patriarchy, but whether or not it necessarily decreases girls' education is complicated to discern. Some Kurdish families stated that when they had to move from rural areas to the cities because of the ethnic conflict, the family pressure not to send the girls to school decreased. The interviews suggested that the hierarchical gender relations were stronger in rural areas than they were in urban neighborhoods. For instance, in explaining why she did not go to school, a woman in her late forties explained that she did not even have the idea that girls went to school. At the time of her school age, she and her family lived in a village. Because of the migration history of the families, we observed an increased schooling rate among the younger girls as compared to the older ones. In almost all the cases where the oldest daughter did not go to school, the family had previously lived in a village. But after moving to the city, the family sent the younger children to school.

Our interview data suggest that, in addition to economic reasons and the availability of schools in villages, the high level of clan (aşiret) pressure in the villages played a significant role in the low level of schooling among the villagers. When there were no schools in their own villages, the children had to be transferred to other villages for school, affecting the calculus and costs of the decision. However, our interviews show that the real influence of migration was on the weakening of patriarchy. As families migrated to new environments in which they were distant from their clan and extended family, they were more likely to send girls to school. In this case, ethnic conflict, by ameliorating patriarchal social relations, unintentionally increases the schooling of girls in southeastern Turkey.

\section{Ethnic conflict, socio-economic development, and gender inequality in education}

The dominance of ethnic problems during the last four decades stalled the economic development by preventing the expansion of business opportunities 
into the southeastern cities in Turkey. Although the state initiated the Southeastern Anatolia Project to help development in the region, the issues of safety and stability prevented the private sector from heavily investing in the region. The weakness of socio-economic development helps sustain traditional patriarchal structures and creates obstacles for the schooling of girls. ${ }^{61}$ The interviews show that socio-economic conditions stemming from ethnic conflict influence girls' schooling.

Among the Kurdish parents, one recurring theme was the influence of seasonal work on girls' schooling. Several families indicated that they worked in Western cities as seasonal workers in the months when school was open. The families went to these cities with their children and worked in the farms or construction projects together. The shortage of jobs in their own locales led them to leave their villages and pull their children from school. Although this influenced both boys and girls, some efforts were made to keep boys in school (such as leaving them with grandparents) but they did not give a similar level of attention to girls' schooling. The motivation behind the move is either to keep girls with them for safety issues or the belief that boys needed to complete school to find a job.

As parents become better off economically, their patriarchal context dissolves and the tendency to send girls to school increases. The story of a Kurdish parent from our fieldwork supports this observation. In the neighborhood where we had our interviews in Şanlıurfa, all the houses except a few big apartment buildings were slums. We had a chance to interview a Kurdish parent with five children (three girls and two boys) from one of the relatively nicer apartment buildings. The family had moved from one of the slum flats into a flat in the apartment building after the father found a stable job in the city government. The father was an elementary school graduate and the mother never went to school. Although the eldest daughter was somewhat unenthusiastic about going to school, they were pushing her to complete high school and work toward university. When we asked what the extended family thought about their decision to send the girls to school, the mother said, 'It was the thing of the past.' She also indicated that 'today, you're blamed for not sending your daughters to school.' However, we had just observed respondents blaming other parents for sending their daughters to school one street away. This example suggests that changing the environment even a little bit can decrease social pressure and promote tendencies to send girls to school.

Although the impact of ethnic conflict on socio-economic development is clear, the underdevelopment did not influence only the Kurdish families. Among Arab parents, however, socio-economic issues were not cited as a significant obstacle for the schooling of girls even though some parents faced these issues; the pressure of the clan was the paramount reason cited for low schooling of girls among the Arabs. But a majority of Turkish parents 
in Gaziantep cited poverty as a reason for not sending girls to school. School expenses are too much to afford for some families. A father in his fifties cried during the interview when he remembered the day that he could not afford his daughter's picnic money. A mother from Gaziantep indicated that her older daughter dropped out because of the school expenses while only the youngest one still attended elementary school.

In line with earlier studies, almost all the parents that we interviewed claimed that state support helped them send both boys and girls to school. ${ }^{62}$ In Turkey, the state provides textbooks to students and gives a stipend to low-income families for sending each child to school. The state also encourages parents to send girls to school by paying $50 \%$ more of the stipend for girls than for the boys. The state directly deposits those stipends into the mothers' banking accounts every three months. Although the state support helped the families, it was not significant enough to create a stable income for the parents. ${ }^{63}$ Several parents complained that the support was not enough to keep all of their children at school. For example, one mother from Gaziantep indicated her appreciation of the state support for her children's education, but she still complained that keeping the children at school was a high cost for the family and that they had to stop the education of their older daughter. Many Kurdish and Turkish parents complained about the financial difficulties of continuing studies after elementary school, after which the state stops supporting parents.

The lack of economic opportunities, in combination with the strength of patriarchy, can be seen even in the expectations of parents who send their girls to school. Those parents (especially among the Arab parents who defended the necessity of girls' schooling) justified their position by reference to the need to become literate to meet women's everyday needs. For example, an Arab woman in her thirties said 'I didn't go to school. I am illiterate. I cannot find the right bus to go to the doctor. I don't want my daughters suffer the same problems that I did.' An Arab male respondent concurred when talking about his sister who never went to school. 'If I leave my sister alone downtown, she cannot find home. I don't want my daughters to be like that.'

Only a few parents, particularly from the Kurdish and Turkish origins, stated that going to school might provide something more than pragmatic than 'getting by' in the long run, such as a career to their daughters. Such short-term pragmatism may explain the parents' unwillingness to send their daughters to school after they graduate from elementary program. However, several parents, particularly from Kurdish and Turkish descent, indicated that when they see educated women in hospitals, and schools, it encourages them to send their daughters to school. The existence of educated women role models is an important psychological motivation for some parents to rebuke the patriarchy and send their girls to school. For example, a Kurdish woman in her forties stated: 'when we go to a hospital, 
we want to be treated by female doctors. If we don't send our daughters to school, where will those female doctors come from?' A mother in Gaziantep referred to the interviewer stating, 'Of course I would like if my daughter could be like you, a teacher in University... I would be very proud.' However, even with aspirations of education for their daughters, mothers often expressed ambivalent feelings about whether girls could fulfill both professional and cultural roles.

\section{Ethnic conflict, political mobilization, and gender inequality in education}

Despite our expectation that concerns of state assimilation of the Kurdish identity would prevent the Kurdish parents from sending their children, including the girls, to school, we did not find evidence to support this claim. Surprisingly, we found out that the conflict around ethnic identity and the Kurdish political mobilization as a reaction to it undermined the power of patriarchy among the Kurds. In contrast to our expectations, we found that the patriarchal structures appear to be stronger among Arabs than they are among Kurds. Traditional patriarchal codes constitute an obstacle to schooling of girls for both Arabs and Kurds, but in differing degrees. The elders of the clan appear to have more power over Arab families while the father is the decision maker among Kurdish families. This difference might lie in the degree of cosmopolitanism among Kurds and Arabs. The Kurdish nationalist movement might have weakened the power of clan in favor of a more cosmopolitan Kurdish national identity. The lack of a broader identity claim among Arabs might have contributed to the sustenance of clan culture and patriarchies upon which this culture rests. ${ }^{64}$

We asked the feelings of the respondents about the state support for education if they considered it as a tool of state assimilation of their children in Şanlıurfa. We did not find a clear difference in attitudes between Kurds and Arabs. During the interviews, some parents did have suspicions about the stipend that the state pays to mothers for each child that attends school. They questioned the intent of the state, but surprisingly, these parents were from Arab families. The Kurdish families did not voice such a concern.

Kurdish political mobilization seems to have undermined traditional patriarchal network among the Kurds. As the narratives told by interviewees mark, the tribal links among the Arab families are stronger than they are among the Kurdish families. In both Kurdish and Arab families, mothers have less influence over decisions of sending girls to school. However, among the Arab families, even the father has little leverage on the issue. The decisions are made by the clan through informal social pressures. One woman in her late thirties mentioned how her clan prevented her daughter from continuing school: 
After my daughter completed the fifth grade, she wanted to continue school. Her father was also willing to send her to school. However, our clan didn't allow us to send her to school. Because she grew up really fast and she was very tall they thought it would not be appropriate to send a mature girl to school.

When the male members of the family such as fathers or grandfathers were absent during the interviews, the Arab women openly indicated that the clan structure, aşiret, was the major obstacle for the schooling of girls. These women indicated that the decision makers in the family were the elder males in the clan, sometimes grandfathers or uncles. In several cases, the parents sent their kids to school until fifth grade and stopped sending them after that. The women interviewees indicated that the extended family put pressure on parents if they decided to send the girls after they reached puberty. In most cases, the girls were sent to school only until puberty. Some women interviewees said that the extended family implemented sanctions through shaming. A woman in her thirties said that those girls who went to school after puberty might find it difficult to get married. While some literature argued that education level 'can be considered as both a cause and a consequence of early marriage, ${ }^{, 65}$ we only found instances of families, particularly among our Arab respondents, pulling their daughters out of school early as a strategy to make them more marriageable. When a male member of the family was involved in an interview, the extended family influence was less mentioned. The fathers also expressed unwillingness to send girls to school after puberty but they downplayed the role of the extended family as an explanation. They mostly addressed the 'threats' outside of the neighborhood for girls.

In Kurdish families, the clan plays a smaller role in decisions to send girls to school. The fathers within the nuclear families seem to make most of the decisions. Only a few Kurdish families referred to the role of the extended family in making decisions to send the girls to school. Even in those families, the room to make decisions within the family was clearly larger than among their Arab counterparts. A Kurdish mother in her forties, for example, said that despite some people in the extended family blamed her and her husband for sending their daughters to school, they decided to send girls to school because they saw it as the girls' right. When faced with clan pressure and their own judgment, they chose the latter. None of the Arab parents spoke of defying extended family pressure with this clarity.

In short, our interview data singled out the culture of patriarchy as the main reason for the gender inequality in education with socio-economic conditions playing a partial role. Ethnic conflict contributes to gender inequality in education by sustaining the patriarchy either by creating an environment of militarism or by decelerating economic development. However, it is also important to note that the Kurdish conflict weakened the power of feudal 
structures and contributed to a relatively more egalitarian relationship between genders by mobilizing a broader Kurdish national identity.

\section{Conclusion}

Gender inequality has been studied in several other contexts but previous studies have not focused on the relationship between schooling of girls and conflict. Our study attempted to explore the causal link between the two. This study is a fresh yet modest attempt to understand girls' schooling from an ethnic conflict perspective through the lens of the relationship between Turkey's decades-old Kurdish conflict and education.

The study has demonstrated that patriarchy is the single most important determinant of the low level of schooling among girls in southeastern Turkey, and that it overlaps with other determinants including socio-economic status and linguistic marginalization. Urbanization, through undermining patriarchal structures, increases schooling of girls. Ethnic conflict influences schooling through reinforcing patriarchy and limiting socio-economic development in the region. However, political mobilization of the Kurds as a reaction to ethnic conflict, and rural-to-urban migration as a side effect of violence, undermined patriarchal social relations and increased the schooling of girls. Due to these macro-social processes that created an ethno-national identity and weakened patriarchy, the Kurds were more willing to send their daughters to school. Surprisingly, ethno-nationalist identity's impact on patriarchy neutralized the considerations of assimilation in sending the girls to public schools.

This study is a first effort to understand the relationship between conflict and gender inequality in the Turkish context. Further research is needed to investigate the link between political conflict and schooling of girls, both in Turkey and beyond. First, new set of interviews can be conducted with the people from provinces that have been influenced by the political violence more deeply such as in Hakkari, Diyarbakır, or Van. Second, new hypotheses might be generated based on an in-depth study of the Kurdish conflict and schooling of girls in Turkey by an interdisciplinary team of scholars. Further research might examine how schooling of girls is influenced by other conflict-related variables such as number of casualties, the degree of violence in the conflict, or the number of militants participating in terrorist activities in a particular district. Finally, scholars may employ methods other than the fieldwork and interviews to examine the relationship between conflict and gender inequality in education. Methods such as survey-data based quantitative analysis or studies looking at multiple measures of educational achievement and different measures of conflict's effects could explore the relationship in ways that were not explicable in a fieldwork study. 


\section{Notes}

1. UNESCO Institute for Statistics, Global Education Digest; Kaya, Forgotten or Assimilated?; McClure, “Turkey's Eastern Question.”

2. UNESCO Institute for Statistics, Global Education Digest.

3. Chernichovski, "Socio-Economic and Demographic"; Moghadam, Democratic Reform; Acar et al, Cinsiyete Dayalı Ayrimcilik.

4. Gross, "The Politics of Unofficial Language," 177-208.

5. Gündüz-Hoşgör and Smits, "Linguistic Capital”; Smits and Gündüz-Hoşgör, "Linguistic Capital."

6. The emergence of the Kurdish movement in civil society started in the 1990s due to Turgut Özal's liberal reforms; however, the decriminalization of the Kurdish language came only in the 2000s.

7. Chernichovski, "Socio-Economic and Demographic"; Moghadam, Democratic Reform; Acar et al., Cinsiyete Dayalı Ayrimcilik.

8. Bourdieu, "The Economics"; Bourdieu, Language; Gross, "The Politics of Unofficial Language."

9. Shemyakina, "Ordinary Language"; Rankin and Aytaç, "Gender Inequality"; Smits and Gündüz-Hoşgör, "Effects of Family Background."

10. Filmer, "The Structure"; Acar et al., Cinsiyete Dayal Ayrimcilik; Adaman and Keyder, "Poverty and Social Exclusion"; Alat and Alat, "A Qualitative Study"; Bahar, "Education Is Important"; Chernichovski, "Socio-Economic and Demographic"; Erigil, "Results of a Survey"; Smits and Gündüz-Hoşgör, "Effects of Family Background"; Moghadam, Democratic Reform; Herz et al., What Works in Girls' Education; Tansel, "Determinants of School."

11. Kosmol, "Turkey's East-West Economic Divide.”

12. Kirdar, "Explaining Ethnic Disparities," 297-333.

13. Ibid.

14. Adaman and Keyder, "Poverty and Social Exclusion"; Brizic and Yagmur "Mapping Linguistic Diversity"; Uçarlar, "Between Majority Power and Minority Resistance"; Candas et al., Turkiye'de Esitsizlikler"; Kaya, "Forgotten or Assimilated?"; Kirdar, "Explaining Ethnic Disparities."

15. Gross, "The Politics of Unofficial Language," 177-208.

16. May, Language and Minority Rights.

17. Polat and Makalingappa, "Gender Differences in Identity".

18. Gündüz-Hoşgör and Smits, "Linguistic Capital”; Smits and Gündüz-Hoşgör, "Linguistic Captital”; Alat and Alat, "A Qualitative Study," 1369-73.

19. Göle, "Authoritarian Secularism and Islamist Politics."

20. Tekeli, "Emergence of the Feminist Movement in Turkey," 193; White, "State Feminism."

21. Zihnioğlu, Kadınsız Inkılap.

22. Kandiyoti, "Bargaining with Patriarchy." See also, Sirman, “The Making," 163.

23. Arat, The Patriarchal Paradox.

24. Diner and Toktaş, "Waves of Feminism in Turkey."

25. Coşar, Yeğenoğlu, "New Grounds for Patriarchy in Turkey?"

26. Al-Rebholz, "Gendered Subjectivity."

27. Özkaleli, "State of the State in Their Minds."

28. Smits and Gündüz-Hoşgör, "Effects of Family Background."

29. Rankin and Aytaç "Gender Inequality in Schooling," 25-43.

30. Ibid.

31. Erman, "Rural Migrants," 130. 
32. Ibid.

33. Smits and Gündüz-Hoşgör, "Effects of Family Background," 545-60.

34. Cin, and Walker, "Reconsidering Girls' Education."

35. Ertem and Koçtürk, "Opinions on Early-Age Marriage," 147-52.

36. Ibid.

37. Davies, Education and Conflict.

38. Alwy and Schech, "Ethnic Inequalities in Education in Kenya."

39. Kao and Thompson, "Racial and Ethnic Stratification."

40. Stromquist, "Gender Inequality in Education."

41. Bush and Saltarelli, The Two Faces of Education in Ethnic Conflict.

42. Caprioli, "Gender Equality and State Aggression."

43. Sirkeci, "Exploring the Kurdish Population," 149-75.

44. Taşpınar, Kurdish Nationalism; Romano, The Kurdish Nationalist Movement; Yeğen, "Prospective-Turks' or 'Pseudo-Citizens'."

45. Olson, The Kurdish Nationalist Movement, 1-208.

46. Tezcür, "When Democratization Radicalizes"; Efegil, "Analysis of the AKP."

47. Tezcür, "Prospects for Resolution"; Gürses, "Is Islam a Cure for Ethnic Conflict."

48. AltInay, The Myth of the Military-Nation.

49. For more information about the project, see, http://www.gapcatom.org/en (last accessed on September 25, 2017).

50. Ilkkaracan, "Exploring the Context," 67.

51. Ibid.

52. Sen, "Gender and Cooperative Conflicts," 123.

53. Çeliker, Kurdish Life, 95.

54. The Syrian refugees in the later period diversified the population but at the time of our research, there were no Syrian refugee impact in the neighborhoods that we conducted our fieldwork.

55. Brady et al., "Toward a Pluralistic Vision"; Brady, "Causation and Explanation."

56. Leech, "Asking Questions"; Schaffer, "Ordinary Language Interviewing." For other examples of research that included interviews in Southeastern Turkey, see Sahin-Mencutek, Zeynep, "Strong in the Movement" and Gürbüz, Rival Kurdish Movements in Turkey.

57. Ilkkaracan, "Exploring the Context," 66-75.

58. Ahmetbeyzade, "Kurdish Nationalism in Turkey," 187-210.

59. Smits and Gündüz-Hoşgör, "Linguistic Captial," 829-53.

60. Cindoğlu and Unal, "Gender and Sexuality," 50.

61. Day, "The Politics of Poverty," 24-6.

62. Gümüş and Gümüş, "Achieving Gender Parity”; Ilker, "The Capitalist Function"; O’Dwyer et al., "Expanding Educational Access"; Somuncu, "Achieving Universal."

63. In 2014, the state support for the boys was 20 Turkish liras (about 10 US dollars at the time).

64. Mojab, "Vengeance and Violence"; Hassanpour, "The (Re)production of Patriarchy."

65. Yüksel-Kaptanoğlu and Ergöçmen, "Early Marriage,” 1719-20. 


\section{Acknowledgements}

The authors wish to thank Amorette Nelson and Bethany Vailliant for research assistance.

\section{Disclosure statement}

No potential conflict of interest was reported by the authors.

\section{Funding}

This work was supported by University of Nebraska at Omaha's Office for Research and Creative Activity [IRB\# 248-13-EX].

\section{Notes on contributors}

Ramazan Kılınç is an associate professor of political science at University of Nebraska at Omaha.

Jody Neathery-Castro is an associate professor of political science at University of Nebraska at Omaha.

Selin Akyizz is a research fellow at Bilkent University International Advanced Studies Centre.

\section{Bibliography}

Acar, F., A. Güneş-Ayata, and D. Varoğlu. “Cinsiyete Dayalı Ayrımcılık: Türkiye’de Eğitim Sektörü örneği: Cinsiyete Dayalı Ayrımcılık ve Kadın çalışanlara Karşı Tutumlar: Türkiye'de Eğitim Sektörü örneği.” TC Başbakanlık Kadının Statüsü ve Sorunları Genel Müdürlüğü, 1999.

Adaman, F., and Ç. Keyder. "Poverty and Social Exclusion in the Slum Areas of Large Cities in Turkey." Report for the European Commission, Employment, Social Affairs and Equal Opportunities, 2006.

Ahmetbeyzade, C. "Kurdish Nationalism in Turkey and the Role of Peasant Kurdish Women." In Gender Ironies of Nationalism: Sexing the Nation, edited by Tamar Meyer, 187-210. London: Routledge, 2012.

Alat, Z., and K. Alat. "A Qualitative Study of Parental Resistance to Girls' Schooling.” Educational Sciences: Theory \& Practice 11, no. 3 (2011): 1369-1373.

Al-Rebholz, A. "Gendered Subjectivity and Intersectional Political Agency in Transnational Space: The Case of Turkish and Kurdish Women's NGO Activists." In Situating Intersectionality, edited by Angelia R. Wilson, 107-129. New York: Palgrave Macmillan, 2013.

Altinay, Ayşe Gül. The Myth of the Military-Nation: Militarism, Gender, and Education in Turkey. New York: Macmillan, 2006.

Alwy, A., and S. Schech. "Ethnic Inequalities in Education in Kenya." International Education Journal 5, no. 2 (2004): 266-274.

Arat, Yeşim. The Patriarchal Paradox, Women Politicians in Turkey. London: Associated University Press, 1989.

Bahar, O. S. “Education Is Important But ... ': Low-Income Kurdish Migrant Mothers' Beliefs About Child Education and Child Labor.” Journal of Global 
Social Work Practice 4, no. 2 (2011). http://www.globalsocialwork.org/vol4no2/ Bahar.html.

Bourdieu, P. “The Economics of Linguistic Exchanges." Social Science Information 16, no. 6 (1977): 645-668.

Bourdieu, Pierre. Language and Symbolic Power. Cambridge: Harvard University Press, 1991.

Brady, H. E. "Causation and Explanation in Social Science." In The Oxford Handbook of Political Methodology, edited by Janet M. Box-Steffensmeier, Henry E. Brady, and David Collier, 217-270. New York: Oxford University Press, 2008.

Brady, H. E., D. Collier, and J. Seawright. "Toward a Pluralistic Vision of Methodology." Political Analysis 14, no. 3 (2006): 353-368.

Brizic, K., and K. Yagmur. "Mapping Linguistic Diversity in an Emigration and Immigration Context: Case Studies on Turkey and Austria." Mapping Linguistic Diversity in Multicultural Contexts 94 (2008): 245-264.

Bush, Kenneth David, and Diana Saltarelli. The Two Faces of Education in Ethnic Conflict: Towards a Peacebuilding Education for Children. Florence: UNICEF Innocenti Research Centre, 2000.

Caprioli, M. "Gender Equality and State Aggression: The Impact of Domestic Gender Equality on State First Use of Force." International Interactions 29, no. 3 (2003): 195-214.

Celiker, Anna Grabolle. Kurdish Life in Contemporary Turkey: Migration, Gender and Ethnic Identity. Vol. 2. London: IB Tauris, 2013.

Chernichovski, D. "Socio-Economic and Demographic Aspects of School Enrollment and Attendance in Rural Botswana." Economic Development and Cultural Change 33, no. 2 (1985): 319-332.

Cin, F. M., and M. Walker. "Reconsidering Girls' Education in Turkey from a Capabilities and Feminist Perspective." International Journal of Educational Development 49 (2016): 134-143.

Cindoglu, D., and D. Unal. "Gender and Sexuality in the Authoritarian Discursive Strategies of 'New Turkey'." European Journal of Women's Studies 24, no. 1 (2017): 39-54.

Cosar, S., and M. Yegenoglu. "New Grounds for Patriarchy in Turkey? Gender Policy in the Age of AKP." South European Society and Politics 16, no. 4 (2011): 555-573.

Davies, Lynn. Education and Conflict: Complexity and Chaos. New York: Routledge, 2003.

Day, W. “The Politics of Poverty in Turkey's Southeast.” Middle East Report, 24-26, 2008. http://www.merip.org/mer/mer247/politics-poverty-turkeys-southeast.

Diner, C., and Ş. Toktaş. "Waves of Feminism in Turkey: Kemalist, Islamist and Kurdish Women's Movements in an Era of Globalization." Journal of Balkan and Near Eastern Studies 12, no. 1 (2010): 41-57.

Efegil, E. "Analysis of the AKP Government's Policy Toward the Kurdish Issue." Turkish Studies 12, no. 1 (2011): 27-40.

Erman, T. "Rural Migrants and Patriarchy in Turkish Cities." International Journal of Urban and Regional Research 25, no. 1 (2001): 118-133.

Ertem, M., and T. Kocturk. "Opinions on Early-Age Marriage and Marriage Customs among Kurdish-Speaking Women in Southeast Turkey." Journal of Family Planning and Reproductive Health Care 34, no. 3 (2008): 147-152.

Filmer, D. The Structure of Social Disparities in Education: Gender and Wealth. Policy Research Working Paper No. 2268. Washington, DC: World Bank, 2000. 
Göle, Nilüfer. "Authoritarian Secularism and Islamist Politics: The Case of Turkey.” In Civil Society in the Middle East, edited by A. R. Norton, 17-43. Leiden: E. J. Brill, 1996.

Gross, J. E. "The Politics of Unofficial Language Use Walloon in Belgium, Tamazight in Morocco." Critique of Anthropology 13, no. 2 (1993): 177-208.

Gümüş, S., and E. Gümüş. "Achieving Gender Parity in Primary School Education in Turkey via the Campaign Called'Haydi Kizlar Okula' (Girls, Let's Go to School).” Education and Science 38, no. 167 (2013): 17-26.

Gündüz-Hoşgör, A., and J. Smits. Linguistic Capital: Language as a Socio-Economic Resource among Ethnic Women in Turkey. Mimeograph. Ankara: Middle East Technical University, 2001.

Gürbüz, Mustafa. Rival Kurdish Movements in Turkey: Transforming the Ethnic Conflict. Amsterdam: Amsterdam University Press, 2016.

Gürses, M. "Is Islam a Cure for Ethnic Conflict: Evidence from Turkey." Politics and Religion 8, no. 1 (2015): 135-154.

Hacettepe University Institute of Population Studies Turkey Demographic and Health Survey, 2008. Hacettepe University Press, 2009.

Hassanpour, Amir. "The (Re) Production of Patriarchy in the Kurdish Language." Women of a Non-State Nation. The Kurds. Kurdish Studies Series, no. 3 (2001): 227-263.

Herz, Barbara Knapp, and Gene B. Sperling. What Works in Girls' Education: Evidence and Policies from the Developing World. New York: Council on Foreign Relations, 2004.

Ilker, C. B. "The Capitalistic Function of Education-Directed Social Responsibility Projects in Turkey Within the Context of Relationships Between the Private Sector and NGOs." Journal for Critical Education Policy Studies 6, no. 1 (2008): 224-243.

Ilkkaracan, P. "Exploring the Context of Women's Sexuality in Eastern Turkey." Reproductive Health Matters 6, no. 12 (1998): 66-75.

Kandiyoti, D. "Bargaining with Patriarchy." Gender and Society 2, no. 3 (1988): 274290.

Kao, G., and J. S. Thompson. "Racial and Ethnic Stratification in Educational Achievement and Attainment." Annual Review of Sociology 29 (2003): 417-442.

Kaya, Nurcan. Forgotten or Assimilated? Minorities in the Education System of Turkey. London: Minority Rights Group International, 2009.

Kurdar, M. G. "Explaining Ethnic Disparities in School Enrollment in Turkey." Economic Development and Cultural Change 57, no. 2 (2009): 297-333.

Leech, B. L. “Asking Questions: Techniques for Semistructured Interviews.” Political Science \& Politics 35, no. 4 (2002): 665-668.

May, Stephen. Language and Minority Rights: Ethnicity, Nationalism and the Politics of Language. London: Routledge, 2013.

McClure, K. R. "Turkey's Eastern Question: Educational Disparities and EU Accession." The Washington Review of Turkish \& Eurasian Affairs, February 2011. www.washingtonreview.org/articles/turkeys-eastern-question-educationaldisparities-and-eu-accession,html.

Moghadam, Valentine M. Democratic Reform and the Position of Women in Transitional Economies. Oxford: Clarendon Press, 1993.

Mojab, S. "Vengeance and Violence: Kurdish Women Recount the War." Canadian Woman Studies 19, no. 4 (2000): 89-94. 
O’Dwyer, J., N. Aksit, and M. Sands. "Expanding Educational Access in Eastern Turkey: A New Initiative." International Journal of Educational Development 30, no. 2 (2010): 193-203.

Olson, Robert. The Kurdish Nationalist Movement in the 1990s. Lexington: University of Kentucky Press, 1996.

Ozkaleli, U. "State of the State in Their Minds: Intersectional Framework for Women's Citizenship in Turkey." Women's Studies International Forum 48 (2015): 93-102.

Polat, N., and L. J. Mahalingappa. "Gender Differences in Identity and Acculturation Patterns and L2 Accent Attainment." Journal of Language, Identity, and Education 9, no. 1 (2010): 17-35.

Rankin, B. H., and I. A. Aytaç. "Gender Inequality in Schooling: The Case of Turkey." Sociology of Education 79, no. 1 (2006): 25-43.

Romano, David. The Kurdish Nationalist Movement: Opportunity, Mobilization, and Identity. Cambridge: Cambridge University Press, 2006.

Sahin-Mencutek, Z. "Strong in the Movement, Strong in the Party: Women's Representation in the Kurdish Party of Turkey." Political Studies 6, no. 2 (2016): 470-487.

Schaffer, F. C. “Ordinary Language Interviewing." In Interpretation and Method. Empirical Research Methods and the Interpretative Turn, edited by D. Yanow and P. Schwartz-Shea, 150-160. London: Routledge, 2006.

Sen, Amartya. Gender and Cooperative Conflicts. Working Papers. Helsinki: Wider, 1987.

Shemyakina, O. "The Effect of Armed Conflict on Accumulation of Schooling: Results from Tajikistan." University of Sussex, HiCN Working Paper. Households in Conflict Network, 2006.

Sirkeci, I. "Exploring the Kurdish Population in the Turkish Context." Genus 56, no. 1-2 (2000): 149-175.

Sirman, N. "The Making of Familial Citizenship in Turkey.” In Citizenship in a Global World, European Questions and Turkish Experiences, edited by E. F. Keyman and A. Içduygu, 147-172. New York: Routledge, 2005.

Smits, J., and A. Gündüz-Hoşgör. "Linguistic Capital: Language as a Socio-Economic Resource among Kurdish and Arabic Women in Turkey." Ethnic \& Racial Studies 26, no. 5 (2003): 829-853.

Smits, J., and A. Gündüz Hoşgör. "Effects of Family Background Characteristics on Educational Participation in Turkey." International Journal of Educational Development 26, no. 5 (2006): 545-560.

Somuncu, M. “Achieving Universal Primary Education in Mountains: Turkey's Education Campaign for Girls:'Off to School, Girls!'('Haydi KIzlar Okula!').” Mountain Research and Development 26, no. 1 (2006): 20-23.

Stromquist, N. P. "Gender Inequality in Education: Accounting for Women's Subordination." British Journal of Sociology of Education 11, no. 2 (1990): 137-153.

Tansel, A. "Determinants of School Attainment of Boys and Girls in Turkey: Individual, Household and Community Factors." Economics of Education Review 21, no. 5 (2002): 455-470.

Taspinar, Omer. Kurdish Nationalism and Political Islam in Turkey: Kemalist Identity in Transition. New York: Routledge, 2004.

Tekeli, Şirin. "Emergence of the Feminist Movement in Turkey." In The New Women's Movement, edited by D. Dahlerup, 179-199. Thousand Oaks, CA: Sage, 1986. 
Tezcür, M. G. "When Democratization Radicalizes: The Kurdish Nationalist Movement in Turkey." Journal of Peace Research 47 (2010): 775-789.

Tezcür, M. G. "Prospects for Resolution of the Kurdish Question: A Realist Perspective." Insight Turkey 15 (2013): 69-84.

Uçarlar, Nesrin. Between Majority Power and Minority Resistance: Kurdish Linguistic Rights in Turkey. Lund: Department of Political Science, Lund University, 2009.

UNESCO Institute for Statistics. "Think Piece Commissioned for the EFA Global Monitoring Report 2011, The Hidden Crisis: Armed Conflict and Education.” September 2010.

UNESCO Institute for Statistics Global Education Digest: Comparing Education Statistics Across the World. 2010. Montreal, Canada: UNESCO Institute for Statistics, 2010.

White, J. B. "State Feminism, Modernization and the Turkish Republican Woman." National Women's Studies Association Journal 15, no. 3 (2003): 145-159.

Yeğen, M. “'Prospective-Turks' or 'Pseudo-Citizens': Kurds in Turkey.” The Middle East Journal 63, no. 4 (2009): 597-615.

Yüksel-Kaptanoglu, İ., and E. Akadli. “Early Marriage: Trends in Turkey, 1978-2008.” Journal of Family Issues 35, no. 12 (2014): 1719-1720.

Zihnioglu, Yaprak. Kadinsiz Inkilap. Istanbul: Metis, 2003. 